daisy disease as a reminder to look for the usual buttock rash), nor were the ulcers palatal only. The clinical diagnosis at the time was primary herpes stomatitis. It was noted that his daughter might have had a similar episode two weeks previously. At follow-up two weeks later the patient had an obvious but mild hemifacial weakness of one week's duration. He had noted also slight numbness in the distribution of the maxillary branch of the trigeminal nerve but no other neurological deficit. Investigation at this time showed very high antibody titres to HSV and varicella-zoster $(\mathrm{V}-\mathrm{Z})$ but no elevation of the Coxsackie A16 titre. The Paul-Bunnell test was negative and there was no deficiency in the immune globulin profile. No specimen was taken from the mouth ulcers, which were by then healed. The facial weakness recovered in about a month.

That primary herpes simplex infections occur in adults is well recognised and the diagnosis is confirmed here by the high antibody titre. The $\mathrm{V}-\mathrm{Z}$ antibody titre was also elevated but this has been noted before in older patients with primary herpes simplex infections. ' The Bell's palsy may have been coincidental but it is probable that the HSV infection was causative. This would seem to add further support to the theory that HSV may be involved in the aetiology of Bell's palsy and general practitioners, who invariably manage. both HSV infections and Bell's palsy, are to be encouraged to search for more evidence of this association.

P GROUT

Conway, Gwynedd

McCormick, D P, Lancet, 1972, 1, 937 . Adour, $\mathrm{K} \mathrm{K}$, et al, Yournal of the American Medical
Association, 1975, 233, 527 .

${ }^{3}$ Lewis, B F, et al, Lancet, 1976, 1, 100.

Schmidt, $\mathrm{N} T$ T, et al, fournal of General Virology,
$1969,4,321$.

\section{Improving drug compliance after hospital discharge}

SIR,-Dr Elspeth Macdonald and her colleagues (3 September, p 618) would no doubt care to hear of the Swedish Dosett. It consists of 28 small compartments with transparent sliding panels, days of the week being marked across the top and four different times down the side. Drugs can be put out for a week and patients can see at a glance whether the dose has been taken or not. It is obtainable from E H Farma, Box 12171, S-102 25 Stockholm 12, Sweden.

St David's Hospital,

A R KEMP

Carmarthen

\section{The urethral syndrome}

SIR,-Your leading article (3 September, p 593), in dividing women suffering from recurrent frequency and dysuria into those with bacteriuria and those with a sterile urine, overlooks a third group who have asymptomatic bacteriuria and coincidentally acquire symptoms not caused by bacteriuria. Probably most of those whose symptoms last less than 24 hours and are found to have bacteriuria are in this group. They are not helped by antimicrobial therapy or measures intended to prevent infection.

The paper cited ${ }^{1}$ alleging benefit from internal urethrotomy was followed by a brief report $^{2}$ of a smaller but otherwise identical series of my own in which the patients were examined by cystoscopy and treated only by reassurance of the absence of serious disease and by simple commonsense advice. The proportions of those patients who had no symptoms who were definitely improved at followup after a minimum of two years were almost identical in the two series, allowing the comment, "Nothing works better than internal urethrotomy."

However, you are right to advocate thorough investigation for these patients, but this is mainly because such investigation allows the patient to be reassured that serious disease is not present. Fear of urogenital disease is, in my experience, a very important factor in exacerbating or maintaining this troublesome syndrome.

North Ormesby Hospital,

Middlesbrough, Clevelan

Farrar, D J, Green, $\mathrm{N} A$, and Ashken, $M \mathrm{R} \mathrm{H}$, British fournal of Urology, 1973, 45, 610. Hole, R, British fournal of Urology, 1973, 45, 615.

SIR,-Your comprehensive review of the urethral syndrome (3 September, p 593) prompts me to ask if any share my belief that the condition occurs in males as well as in females.

W FOWLER

\section{VD Department,}

Birmingham

\section{Helping mothers to love their babies}

SIR,-Your leading article on mothers and babies (3 September, p 595) is welcome. But why should the baby only "be shown briefly to the mother immediately after birth" and then be removed while the third stage of labour is completed? As a medical student in Glasgow 20 years ago I was taught that the baby should be put to the mother's breast immediately after birth and that the reflex contraction of the uterus resulting from the attempts to suckle of a healthy baby will expel the placenta and any blood clots, so speeding up the third stage without need for interference by third parties.

The idea that a mother needs to "rest" after delivery and that to achieve this she must be separated from her infant is probably responsible for many failures to establish breastfeeding. Lip-service is paid to the idea of breast-feeding, but if babies are taken away and given bottles they do not suck hard enough to establish a good flow of breast milk and the mother decides that she does not have enough milk for her baby and gives up. Normal babies should be allowed to sleep beside their mothers and they and their mothers should never see a feeding bottle. Then mothers and others might discover that breast-feeding really is possible, pleasureable, and economic and helps in the involution of the uterus - all of which seems obvious in communities where bottle-feeding has not yet been introduced.

For breast-feeding to continue successfully working mothers should be allowed and encouraged to take their babies to work with them. In most occupations this should be possible, and a contented baby will rarely make a disturbance if given a cuddle and a suck at reasonable intervals and, preferably, parked where it can see its mother. For this to happen probably requires a change in social attitude to make it acceptable for a mother to feed her infant in public, as it is among most of the population of the world. It is ironic that we seem to regard sexually provocative dress, or undress, by nubile girls as acceptable but the putting of her baby to the breast in public by a mother as indecent (though permissible in mediaeval paintings of the Virgin and Child). Breast is best!

Department of Tropica

Community Health School of Tropical Medicine,
Liverpool

\section{Carbon dioxide-dependent dwarf staphylococcus}

SIR,-Hale, ${ }^{1}$ in 1951 , was the first to record the isolation from an abscess of a dwarfcolony Staphylococcus aureus which was dependent on carbon dioxide for characteristic growth. Dwarf variants of a number of phage types, with similar requirements for $\mathrm{CO}_{2 .}$, were then reported from several laboratories, $=$ is isolated from patients who had received antibiotic treatment. We studied strains; isolated from a stye to which topical penicillin had been applied, from an untreated palmar abscess in a household contact, and from the nasopharynx of the patients concerned. On aerobic culture plates there grew only minute unpigmented colonies which were coagulaseand catalase-negative and thus "unrecognisable" as $S$ aureus. However, parallel cultures at $37 \mathrm{C}$ on plates containing $0.3 \%$ sodium bicarbonate as a $\mathrm{CO}$, source or incubated in jars with $1-10 \%$ of $\mathrm{CO}_{2}$ grew normally. It was found that coagulase, catalase, and pigment production varied with colony size, which was measurably $\mathrm{CO}_{2}$-dependent. These strains grew better at $30 \mathrm{C}$ than at $37 \mathrm{C}$ in air but in $\mathrm{CO}$, they grew best at $37 \mathrm{C}$. As has been indicated in your columns recently (Dr M Rahman, 30 July, p 319; Dr A Beck and $\mathrm{Mr}$ G Hounsome, 27 August, p 582), it can be important clinically that such atypical strains of $S$ aureus are recognised.

MAIR THOMAS

Elizabeth Garrett Anderson Hospital,

London NW

Hale, J H, British fournal of Experimental Pathology, $1951,32,307$.

Sherris, J C, fournal of Clinical Pathology, 1952, 5, 534.

ise, R I, and Spink, W W, fournal of Clinical Trvestigation, 1954, 33, 1611.

(9) Pathology, 1955, 8, 284 .

\section{Koch or Henle?}

SIR,-In a review of a book on viral infections edited by Alfred S Evans (3 September, p 630), Professor A P Waterson says that Jakob Henle formulated Koch's postulates "several years before Koch himself did" and that Evans prefers to speak of "the Henle-Koch postulates." This is one of the medicohistorical myths that continue to be repeated by authors who do not consult primary sources.

The original authors of this particular myth were Fildes and McIntosh ${ }^{1}$ who, 58 years ago, claimed: "These are not Koch's postulates, but Henle's." Their claim was made in a paper of 24 pages purporting to prove by the application of Koch's postulates that the influenza pathogen was not a "filter-passer" but "Bacillus influenzae." In fact, all that Henle said was that if living animalcules or distinct plants were found in contagious materials they 